\title{
Komentarz do „Wytycznych UEMS”
}

\author{
Prof. dr hab. n. med. Aleksander Sieroń \\ Krajowy Konsultant w Zakresie Angiologii
}

Ujednolicenie wymagań dla poszczególnych specjalizacji lekarskich w Europie jest potrzebne między innymi w związku z istniejącą migracją lekarzy. W kilku specjalnościach udało się doprowadzić do uznania specjalizacyjnego egzaminu europejskiego jako równoważnego dla polskiego tytułu lekarza specjalisty. Komentowane "Wytyczne” opublikowane w kwietniu tego roku w czasopiśmie „International Angiology” są według autora komentarza, będącego także współautorem „Wytycznych”, milowym krokiem do osiągnięcia jednolitych wymagań stawianych europejskim specjalistom z zakresu angiologii. Jednak, z czego piszący te słowa zdaje sobie sprawę, istnieje pewna trudność $w$ jednoznacznym przełożeniu omawianych „Wytycznych” na wymagania istniejące $w$ poszczególnych krajowych programach specjalizacji. Dotyczy to zresztą nie tylko Polski, ale i krajów, w których taka specjalizacja istnieje. Co więcej, istnieją także kraje, w których współcześnie brakuje państwowego egzaminu specjalizacyjnego $\mathrm{z}$ angiologii.

Nie zmienia to faktu, że „Wytyczne” zawierają logicznie przedstawione wymagania merytoryczne stawiane kandydatom do uzyskania stopnia specjalisty $w$ zakresie angiologii, zresztą praktycznie pokrywające się z wymaganiami stawianymi lekarzom przystępującym do Państwowego Egzaminu Specjalizacyjnego w Polsce. Stworzenie w przyszłości Europejskich Ośrodków Szkolenia może wpłynąć na poprawę i ujednolicenie świadczeń z zakresu angiologii w Europie, co jest głównym celem autorów „Wytycznych”. Tak więc w mojej ocenie „Wytyczne” są ważnym, ale nie ostatecznym krokiem do poprawy jakości w zakresie diagnostyki i terapii chorób naczyń obwodowych w Europie. 